\title{
Evaluation of the open and laparoscopic appendectomy operations with respect to their effect on serum IL-6 levels
}

\author{
Mehmet Kadir Bartın, M.D.,, ${ }^{1}$ Özgür Kemik, M.D., ${ }^{2}$ Mehmet Ali Çaparlar, M.D., ${ }^{3}$ \\ Mustafa Taner Bostancı, M.D., ${ }^{3}$ Muzaffer Önder Öner, M.D. ${ }^{1}$ \\ ${ }^{1}$ Department of General Surgery, Van Training and Research Hospital, Van-Turkey \\ ${ }^{2}$ Department of General Surgery, Yüzüncü Yıl University Faculty of Medicine, Van-Turkey \\ ${ }^{3}$ Department of General Surgery, Dışkapı Yıldırım Beyazıd Training and Research Hospital, Ankara-Turkey
}

\begin{abstract}
BACKGROUND: Postoperative serum inflammatory cytokine levels are thought to reflect the magnitude of surgical stress. Cytokine interleukin-6 (IL-6) is an early marker of systemic inflammatory response and tissue damage. This study evaluated levels of IL-6 after open and laparoscopic appendectomy to compare the degree of surgical stress associated with these procedures.
\end{abstract}

METHODS: IL-6 levels were measured pre- and postoperatively in the plasma of 200 consecutive patients with a diagnosis of acute appendicitis. After preoperative randomization, 100 patients underwent open appendectomy, and 100 patients underwent laparoscopic appendectomy.

RESULTS: Preoperative concentrations of IL-6 were $65.22 \pm 4.76 \mathrm{pg} / \mathrm{mL}$ in the open appendectomy group and $65.73 \pm 6.34 \mathrm{pg} / \mathrm{mL}$ in the laparoscopic appendectomy group $(p=0.752)$. Postoperative levels were $105.28 \pm 16.14 \mathrm{pg} / \mathrm{mL}$ and $76.11 \pm 16.18 \mathrm{pg} / \mathrm{mL}, \mathrm{respectively}$ $(p<0.05)$.

CONCLUSION: Lower postoperative serum IL-6 levels suggest that laparoscopic surgery is associated with lower degree of surgical stress. Laparoscopic appendectomy has significant advantage over open appendectomy due to more rapid postoperative recovery.

Keywords: Interleukin (IL)-6; laparoscopic appendectomy; open appendectomy.

\section{INTRODUCTION}

Although its characteristics and treatment have been accurately defined, acute appendicitis is an urgent surgical condition that can have high mortality and morbidity rates secondary to perforation as result of delayed decision to operate. Therefore, the general tendency is in favor of operating before clinical findings are completely sustained. Consequently, negative appendectomy rates are as high as $30 \%$, which is considered acceptable worldwide. ${ }^{[1]}$ Negative appendectomy has a negligible mortality rate and only $10 \%$ morbidity. Majority of morbidities are traumas due to perioperative

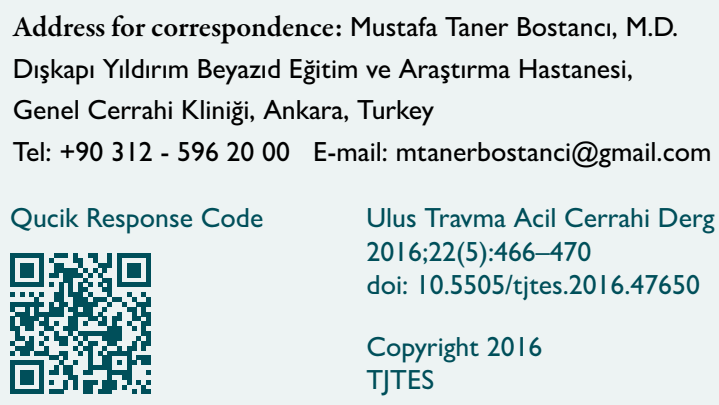

surgery and risk of bride ileus or incisional hernia, which are not life-threatening. ${ }^{[1]}$ There is much lower incidence of perioperative trauma causing critical complications during aggressive surgical treatment of acute appendicitis with laparoscopic appendectomy compared to open conventional surgery. The aim of the present study was to evaluate cases of laparoscopic and open technique appendectomy due to diagnosis of acute appendicitis using interleukin-6 (IL-6) response, a measure of surgical stress, to compare methods of surgical intervention.

\section{MATERIALS AND METHODS}

This study was approved by the ethics committee of Yüzüncü Yıl University Faculty of Medicine Research Hospital on December I, 2010 and given approval number 003. A total of 200 male and female patients of American Society of Anesthesiologists (ASA) physical status classification I or 2, between 16 and 70 years of age, who consecutively presented at the emergency surgery department between July 2010 and December 2014 with prediagnosis of acute appendicitis were included in the study. Patients were evenly distributed into 2 groups: Group I consisted of 100 
patients who had laparoscopic appendectomy, and Group 2 consisted of 100 patients who underwent conventional open appendectomy.

Patients with cardiovascular or pulmonary system disorders, history of abdominal surgery, known allergic history to agents used, history of preoperative anti-inflammatory drug use, infection within abdominal wall, portal hypertension or hepatic cirrhosis, antibiotic medication use, or immunodeficiency were excluded from the study. Unconscious or non-cooperative patients, pregnant patients, and morbidly obese patients were also excluded.

All patients observed preoperative 8-hour period of oral fasting. Premedication, induction of anesthesia, endotracheal intubation, and maintenance of anesthesia were performed according to hospital protocols. Cefazolin sodium I gr was administered intravenously as prophylactic antibiotic after induction of anesthesia.

Five cc venous blood samples were obtained from upper extremity veins just before and 24 hours after the operation for serum IL-6 level testing. Blood samples were taken in dry test tubes and then immediately centrifuged at $3000 \mathrm{rpm}$ for 10 minutes. Top layer of serum was aspirated and put into snap-cap Eppendorf tubes (Eppendorf, Hamburg, Germany) and stored at $-70^{\circ} \mathrm{C}$ in Aeroset refrigerator (Abbott Laboratories, Chicago, IL, USA) in order to perform measurements using spectrophotometry as well as routine tests.

McBurney incision was used to enter abdomen of 84 of the patients who underwent open appendectomy and subumbil- ical median incision was used on 4 patients and paramedian incision was used on 12 patients. All laparoscopic appendectomies were completed using intra-abdominal method with a total of 3 ports. Intra-abdominal area was explored using a $10 \mathrm{~mm}$ port inserted through the umbilicus. Second $10 \mathrm{~mm}$ port was inserted into the abdomen with a direct view at a point approximately $10 \mathrm{~cm}$ below the umbilicus and through the linea alba. The final port, $5 \mathrm{~mm}$ in size, was inserted into the abdomen through the intersection point of midclavicular line and subcostal arch with a direct view. A silastic drain was used on II patients who underwent open appendectomy and 5 patients who underwent laparoscopic appendectomy. Intraoperative macroscopic findings of the patients were recorded. After the operation, pathological results of appendix material and duration of hospital stay were recorded.

Serum samples were tested using enzyme-linked immunosorbent assay method. Specificity and sensitivity of the kit were $90 \%$ and $95 \%$, respectively. ${ }^{[2]}$

Comparison of group means with respect to continuous variables was performed using one-way analysis of variance. Duncan's multiple range test was used to compare the 2 groups. Pearson correlation coefficient was used to determine the association between continuous variables and chi-square test was used for categorical variables. Level of statistical significance was $5 \%(p<0.05)$ and SPSS statistical package software (version 16.0; SPSS Inc., Chicago, IL, USA) was used for data analysis, including Mann-Whitney $U$ test and Friedman test.

Table I. Distribution of demographic data

\begin{tabular}{lccc}
\hline & Group I $(\mathbf{n}=\mathbf{1 0 0})$ & Group 2 $(\mathbf{n}=1 \mathbf{0 0})$ & p \\
\hline Age (Mean \pm SD) & $30.04 \pm 9.26$ & $33.04 \pm 11.28$ & 0.309 \\
Gender (Female/Male) & $64 / 36$ & $48 / 52$ & 0.254 \\
\hline
\end{tabular}

SD: Standard deviation

Table 2. Distribution of histopathological diagnoses

\begin{tabular}{|c|c|c|c|c|c|c|c|}
\hline \multirow[t]{2}{*}{ Histopathological diagnosis } & \multicolumn{2}{|c|}{ Group I } & \multicolumn{2}{|c|}{ Group 2} & \multirow[t]{2}{*}{$\mathbf{p}$} & \multicolumn{2}{|c|}{ Total } \\
\hline & $\mathbf{n}$ & $\%$ & $\mathbf{n}$ & $\%$ & & $\mathbf{n}$ & $\%$ \\
\hline Normal & 4 & 2 & 4 & 2 & $>0.05$ & 8 & 4 \\
\hline Non-suppurative & 64 & 32 & 40 & 20 & $>0.05$ & 104 & 52 \\
\hline Suppurative & 16 & 8 & 28 & 14 & $>0.05$ & 44 & 22 \\
\hline Subacute & 12 & 6 & 20 & 10 & $>0.05$ & 32 & 16 \\
\hline Lymph node hyperplasia & 4 & 2 & 8 & 4 & $>0.05$ & 12 & 6 \\
\hline Total (n) & 100 & 50 & 100 & 50 & & 200 & 100 \\
\hline
\end{tabular}


Table 3. Preoperative and postoperative IL-6 level

\begin{tabular}{lccc}
\hline & Group I $(\mathbf{n}=100)$ & Group 2 $(\mathbf{n}=100)$ & p \\
\hline Preoperative IL-6 $(\mathrm{pg} / \mathrm{mL})$, Mean \pm SD & $65.73 \pm 6.34$ & $65.22 \pm 4.76$ & 0.752 \\
Postoperative IL-6 $(\mathrm{pg} / \mathrm{mL})$, Mean \pm SD & $76.11 \pm 16.18$ & $105.28 \pm 16.14$ & $<0.00 I^{*}$ \\
P & $>0.05$ & $<0.00 I^{*}$ & \\
\hline
\end{tabular}

SD: Standard deviation.

Table 4. Length of hospital stay

\begin{tabular}{lccc}
\hline & Group I $(\mathrm{n}=100)$ & Group 2 (n=100) & p \\
\hline Duration of hospital stay $(\mathrm{h})$, Mean \pm SD & $33.36 \pm 4.38$ & $37.68 \pm 4.68$ & $0.006^{*}$ \\
\hline SD: Standard deviation. & & &
\end{tabular}

\section{RESULTS}

\section{Distribution of the Demographic Data}

No statistically significant difference between groups was found in the demographic data $(p>0.05)$; the distribution is presented in Table I.

\section{Distribution of the Histopathological Diagnoses}

No statistically significant difference with respect to histopathological diagnoses was found between the groups ( $p>0.05)$; the distribution is presented in Table 2 .

\section{Preoperative and Postoperative IL-6 Level}

No significant difference was found between Group I and Group 2 patients with respect to IL-6 levels in the preoperative blood samples $(p<0.05)$. A statistically significant difference was found when comparing preoperative and postoperative serums IL-6 levels in Group 2 patients $(p<0.00 I)$.

When postoperative serum levels were analyzed; IL-6 levels were higher in Group 2 than in Group I $(p<0.00 I)$. A positive correlation was observed between Group 2 and Group I $(r=0.45 ; p<0.00 I)$.

Preoperative and postoperative IL-6 levels are presented in Table 3.

\section{Duration of Hospital Stay}

The duration of hospital stay was statistically lower in Group I compared to Group $2(p<0.05)$ Hospital stay data are presented in Table 4.

\section{DISCUSSION}

IL-6 plays an important role in regulation of inflammatory cells in the immune system; it participates in either proinflammatory or anti-inflammatory reactions. Free tissue injury and infections are the major factors that trigger synthesis of IL-6. It affects the immune system via pattern known as hepatic acute-phase reactions. In this process, cytokines increase the release of acute phase proteins by behaving as general antibodies. Though IL- 6 increases to a certain degree in response to infection, serum IL- 6 level generally increases in reaction to damage of free tissue. Therefore, IL-6 levels don't increase greatly in the picture of acute appendicitis as result of infection in the gastrointestinal system but do increase in cases where tissue damage occurs due to surgical intervention. ${ }^{[3-5]}$

In a study that supports this conclusion, Yildirim et al. ${ }^{\left[{ }^{[1]}\right.}$ investigated leukocyte count, IL-6, and C-reactive protein (CRP) levels in patients with prediagnosis of acute appendicitis. They stated that leukocyte count and CRP levels may be helpful in diagnosis of acute appendicitis. However, they did not evaluate increase in serum IL-6 level as particularly statistically significant with respect to diagnosis of acute appendicitis.

Bachmann et al. ${ }^{[6]}$ determined in literature reviews that inflammatory predictors such as IL-I, IL-2 and IL-10 may provide diagnostic contribution with a low error rate for inexperienced physicians and surgeons. It has been stated that serum levels of these predictors increase significantly in complicated appendicitis, whereas less of an increase occurs in serum levels of IL-6 and IL-8. ${ }^{7]}$ Instead, IL-6 and IL-8 levels see greater increase secondary to perioperative trauma. ${ }^{[6,8]}$ Serum levels of IL- 6 were analyzed in the present study because of this response of these cytokines to stress such as surgical trauma.

Yahara et al. ${ }^{\left[{ }^{[9]}\right.}$ observed in their study that CRP and granulocyte/monocyte colony-stimulating factor levels were high in tissue samples obtained from peritoneal cavity of patients operated on laparoscopically and with open surgery due to diagnosis of acute appendicitis. Preoperative and postoperative CRP and granulocyte/monocyte-colony stimulating fac- 
tor levels of these patients were also high. High preoperative IL-6 levels were detected but were not statistically significant. However, postoperative elevation of this interleukin in conventional surgery patients was significantly higher than in those who had laparoscopic surgery. As expected, total leukocyte and neutrophil counts were high in preoperative period and also in postoperative period after exposure to stress of surgical trauma. In particular, increased neutrophil count may be accepted as a useful marker to indicate level of inflammation in diagnosis of acute appendicitis. ${ }^{[10-12]}$

As in the literature, the present study also found that the difference in serum IL-6 levels tested preoperatively between Group I patients $(65.7 \pm 6.3 \mathrm{pg} / \mathrm{mL})$, who had laparoscopic appendectomy, and Group 2 patients $(65.2 \pm 4.7 \mathrm{pg} / \mathrm{mL})$, who underwent conventional appendectomy, was low and statistically insignificant $(p=0.752)$. The serum IL- 6 levels tested at postoperative $24^{\text {th }}$ hour in both groups $(76.1 \pm 16.1 \mathrm{pg} / \mathrm{mL}$ in Group I and 105.2 $\pm 16.1 \mathrm{pg} / \mathrm{mL}$ in Group 2) were remarkably high, especially in the conventional surgery patients, and the finding was statistically extremely significant $(p<0.00 \mathrm{I})$.

Less surgical trauma in appendectomy leads to early recovery and return to full activity, as was supported by a large-scale meta-analysis conducted by the Cochrane Colorectal Cancer Group. ${ }^{[13]}$ Minimal trauma to abdominal wall during trocar placement and minimal manipulation of intestine causes less pain and encourages faster recovery. ${ }^{[14]}$ The secondary finding of the present study was that mean duration of hospital stay of laparoscopic appendectomy patients was found to be statistically significantly shorter. This advantage of laparoscopic appendectomy was also noted in recent meta-analysis conducted by Sauerland et al. ${ }^{[15]}$

Over time, surgical methods have evolved from open surgery to less invasive techniques. Laparoscopic surgery has also been subject of evolution. Recently, Concha et al. ${ }^{[16]}$ published a review study in which single-incision laparoscopic appendectomy was acknowledged as applicable and comparable procedure in selected patients.

\section{Conclusion}

Surgical interventions create trauma in the body and thereby induce systemic stress response. We have concluded that surgical stress induced by laparoscopic appendectomy is less severe than conventional method of surgical treatment of acute appendicitis.

Additionally, the authors observed that hospital stay was shorter for patients who underwent laparoscopic appendectomy compared to open surgery.
Conflict of interest: None declared.

\section{REFERENCES}

1. Yildirim O, Solak C, Koçer B, Unal B, Karabeyoğlu M, Bozkurt B, et al. The role of serum inflammatory markers in acute appendicitis and their success in preventing negative laparotomy. J Invest Surg 2006;19:345-52.

2. Kemik O, Kemik AS, Dülger AC, Hasırcı İ, Daştan E, Bartın MK, et al. Karaciğer metastazlı kolon kanserli hastalarda interlökin-6 düzeyleri. Van Tip Dergisi 2010;17:42-5.

3. Braga M, Vignali A, Gianotti L, Zuliani W, Radaelli G, Gruarin P, et al. Laparoscopic versus open colorectal surgery: a randomized trial on shortterm outcome. Ann Surg 2002;236:759-67. Crossref

4. Gupta A, Watson DI. Effect of laparoscopy on immune function. Br J Surg 2001;88:1296-306. Crossref

5. Groselj-Grenc M, Repse S, Vidmar D, Derganc M. Clinical and laboratory methods in diagnosis of acute appendicitis in children. Croat Med J 2007;48:353-61.

6. Bachmann LM, Bischof DB, Bischofberger SA, Bonani MG, Osann FM, Steurer J. Systematic quantitative overviews of the literature to determine the value of diagnostic tests for predicting acute appendicitis: study protocol. BMC Surg 2002;2:2. Crossref

7. Türkyilmaz Z, Sönmez K, Karabulut R, Elbeğ S, Moralioğlu S, Demirtola $A$, et al. Sequential cytokine levels in the diagnosis of appendicitis. Scand J Clin Lab Invest 2006;66:723-31. Crossref

8. Montalto AS, Impellizzeri P, Grasso M, Antonuccio P, Crisafi C, Scalfari $\mathrm{G}$, et al. Surgical stress after open and transumbilical laparoscopic-assisted appendectomy in children. Eur J Pediatr Surg 2014;24:174-8.

9. Yahara N, Abe T, Morita K, Tangoku A, Oka M. Comparison of interleukin-6, interleukin-8, and granulocyte colony-stimulating factor production by the peritoneum in laparoscopic and open surgery. Surg Endosc 2002;16:1615-9. Crossref

10. Eriksson S, Granström L, Olander B, Wretlind B. Sensitivity of interleukin- 6 and C-reactive protein concentrations in the diagnosis of acute appendicitis. Eur J Surg 1995;161:41-5.

11. Hallan S, Asberg A, Edna TH. Additional value of biochemical tests in suspected acute appendicitis. Eur J Surg 1997;163:533-8.

12. Sack U, Biereder B, Elouahidi T, Bauer K, Keller T, Tröbs RB. Diagnostic value of blood inflammatory markers for detection of acute appendicitis in children. BMC Surg 2006;6:15. Crossref

13. Wei B, Qi CL, Chen TF, Zheng ZH, Huang JL, Hu BG, et al. Laparoscopic versus open appendectomy for acute appendicitis: a metaanalysis. Surg Endosc 2011;25:1199-208. Crossref

14. Cipe G, Idiz O, Hasbahceci M, Bozkurt S, Kadioglu H, Coskun H, et al. Laparoscopic versus open appendectomy: where are we now? Chirurgia (Bucur) 2014;109:518-22.

15. Sauerland S, Jaschinski T, Neugebauer EA. Laparoscopic versus open surgery for suspected appendicitis. Cochrane Database Syst Rev 2010;10:CD001546. Crossref

16. Concha JA, Cartes-Velásquez R, Delgado CM. Single-incision laparoscopic appendectomy versus conventional laparoscopy in adults. A systematic review. Acta Cir Bras 2014;29:826-31. Crossref 
ORİJINAL ÇALIŞMA - ÖZET

\section{Açık ve laparoskopik apendektomi ameliyatlarının serum IL-6 düzeylerine etkisi açısından değerlendirilmesi \\ Dr. Mehmet Kadir Bartın, ${ }^{1}$ Dr. Özgür Kemik, ${ }^{2}$ Dr. Mehmet Ali Çaparlar, ${ }^{3}$ Dr. Mustafa Taner Bostancı, ${ }^{3}$ Dr. Muzaffer Önder Öner ${ }^{1}$}

${ }^{1}$ Van Eğitim ve Araştırma Hastanesi, Genel Cerrahi Kliniği, Van

${ }^{2}$ Yüzüncü Yıl Üniversitesi Tıp Fakültesi, Genel Cerrahi Anabilim Dalı, Van

${ }^{3}$ Dışkapı Yıldırım Beyazıd Eğitim ve Araştırma Hastanesi, Genel Cerrahi Kliniği, Ankara

AMAÇ: Ameliyat sonrası enflamatuvar sitokinlerin serum düzeylerinin cerrahi stresin boyutunu yansıttığı düşünülür. Sitokin IL-6, sistemik enflamatuvar yanıtın ve doku hasarının erken bir belirtecidir. Bu çalışmanın amacı, açık ve laparoskopik apendektomi sonrası serum IL-6 düzeylerini değerlendirerek bu prosedürlere bağı̆ gelişen cerrahi stres düzeyini karşılaştırmaktır.

GEREÇ VE YÖNTEM: Akut apendisit tanısı almış ardarda gelen 200 hastanın plazmasında ameliyat öncesi ve sonrası IL-6 düzeyleri ölçüldü. Ameliyat öncesi gelişigüzel seçim ile 100 hastaya açık apendektomi ve 100 hastaya da laparoskopik apendektomi yapıldı.

BULGULAR: Ameliyat öncesi IL-6 konsantrasyonu açık grupta $65.22 \pm 4.76 \mathrm{pg} / \mathrm{ml}$ iken laparoskopik grupta ise $65.73 \pm 6.34 \mathrm{pg} / \mathrm{ml} \mathrm{idi} \mathrm{(} \mathrm{p}=0.752)$. Ameliyat sonrası düzeyler ise sırasıyla $105.28 \pm 16.14 \mathrm{pg} / \mathrm{ml}$ ve $76.1 \mathrm{I} \pm 16.18 \mathrm{pg} / \mathrm{ml}$ idi $(p<0.05)$.

TARTIŞMA: Serum IL-6 düzeylerinin daha düşük olması laparoskopik cerrahide cerrahi stres düzeyinin daha düşük olması ile ilişkilidir. Laparoskopik apendektominin daha hızlı ameliyat sonrası iyileşme nedeniyle açık apenedektomiye göre belirgin avantajı mevcuttur.

Anahtar sözcükler: Açık apendektomi; Interlökin(IL)-6; laparoskopik apendektomi.

Ulus Travma Acil Cerrahi Derg 2016;22(5):466-470 doi: 10.5505/tjtes.2016.47650 